\title{
Preliminary estimation of the efficacy of Fusarium sporotrichioides Sherb. as biological control agent against common milkweed (Asclepias syriaca L.)
}

\author{
Tamás Tóth - Arnold Szilágyi - György Kövics \\ University of Debrecen, Faculty of Agricultural, Food Sciences and Environmental Management, \\ Plant Protection Institute, Debrecen \\ toth.tamas@agr.unideb.hu
}

SUMMARY

\begin{abstract}
A study of fungi responsible for severe leaf spots of common milkweed (Asclepias syriaca L.) in the Hajdúság region (East Hungary), Fusarium sporotrichioides and Alternaria alternata were isolated from infested leaf tissues. F. sporotrichioides was the most virulent fungus in pathogenicity tests conducted on healthy leaves of common milkweed plants. Inoculation of common milkweed (A. syriaca) in different growth stages with F. sporotrichioides yielded similar symptoms as the original ones. Spray mixtures containing $1.0 \times 10^{6}$ conidia/ml gave effective control when common milkweed plants were sprayed until runoff occurred. Laboratory (wet chamber) and field experiments showed that asexual spores of the fungal pathogen, $F$. sporotrichioides, exhibited bioherbicidal activity against common milkweed (A. syriaca). More efficient control efficacy was observable on elder plants (at flowering stage) than younger ones. These results initiate that this fungus may be a biocontrol agent for controlling this invasive weed but should clarify its hosts because it could infect cultivated plants as well.
\end{abstract}

Keywords: biocontrol, fungal pathogen, common milkweed, bioherbicide

\section{INTRODUCTION}

Common milkweed (Asclepias syriaca L.) is native to northeastern and north central of United States and some areas of Canada (Bhowmik and Bandeen 1976). A. syriaca is a deep-rooted perennial, and it has become a major weed problem mostly because of the changes in agronomical practices, like reduced tillage and an increased use of soil-applied herbicides, irrigation and fertilizers (Cramer and Burnside 1981). The root system of common milkweed is composed of horizontal and vertical roots. The vertical roots may penetrate the soil to depths of $3.8 \mathrm{~m}$ (Anderson 1999).

A. syriaca is adopted to a wide range of climatic and edaphic conditions (Bhowmik and Bandeen 1976). Infested areas may be found at a wide range of soil conditions almost in every textural group, but infestations are most prevalent on well-drained soils with loamy texture. Actually, it is one of the most noxious and invasive weed species in Hungary, which invades arable lands, horticultural and forestry plantations as well as semi-natural habitats, being a reservoir and host for viruses, other pathogens, and pests (Ulmann 1951, Bhowmik and Bandeen 1976, Horváth et al. 1983, Horváth 1984, Horváth and Szalay-Marzsó 1984, Almási et al. 1999).

A. syriaca is a natural host for Cucumber mosaic virus (CMV). It is a host for western flower thrips (Frankliniella occidentalis) which is the vector of Tomato spotted wilt virus (TSWV), and according to Bagi (1999) the following fungi are parasites of common milkweed: Uromyces asclepiadis, Botrytis cinerea, Golovinomyces cichoracearum, different Fusarium species and numerous fungi from the genuses of Cercospora and Alternaria.

The infestation frequencies of common milkweed varied greatly by land use and crop in Nebraska. There was revealed in a roadside survey, that over $70 \%$ of soybean, oat and sorghum fields were infested with common milkweed. These frequencies for corn, wheat and alfalfa were respectively 36,28 and $6 \%$. At railroads, roadsides and pastures the infestation percentages were of 70, 51 and 14\% (Cramer and Burnside 1982). Evetts (1970) found that in sorghum (Sorghum bicolor (L.) Moench) high infestation of common milkweed caused an average $720 \mathrm{~kg} \mathrm{ha}^{-1}$ yield loss.

Herbicidal control of $A$. syriaca can be varied depending on the herbicide, growth stage, environmental parameters and so on. Various herbicides and combination of them have exhibited a range of efficacy for control of common milkweed as summarized (Cramer and Burnside 1981, 1982).

Because of the increasing importance of common milkweed, and its tolerance to many herbicides, alternative weed control measures are required. In spite demand to develop effective biological control, until now has not been developed a proper control program against A. syriaca.

In summer 2016, common milkweed plants showing symptoms of severe leaf spot disease were observed in different parts of Hajdúság region, in East Hungary (Tóth 2017). Infected leaf and stem samples were collected, and two fungal pathogens (Fusarium sporotrichioides and Alternaria alternata) were isolated and identified.

The use of Fusarium sporotrichioides weed control in arable lands has a concern, because this pathogen has been already identified from cucurbits (Mulenko et al. 2008), sunflower (Mathew et al. 2010), corn, wheat, and barley (Altomare et al. 1997).

The main objectives of this research were (1) to assess the efficacy of artificial inoculation method for progress of disease caused by Fusarium sporotrichioides in common milkweed; and (2) to evaluate weed control efficacy under field conditions. In this study we focused on evolution of disease syndrome caused by $F$. 
sporotrichioides up to the early flowering stage of common milkweed.

\section{MATERIALS AND METHODS}

\section{Fungal isolate and inoculum}

A virulent isolate of $F$. sporotrichioides (FS04) was obtained from our collection of plant pathogenic fungi (University of Debrecen, Plant Protection Institute).

A single spore strain of $F$. sporotrichioides (FS04) previously isolated from infected common milkweed (A. syriaca L.) was collected in Hajdúság region (East Hungary) and it was used in our experiments. The fungus which had been preserved in screw-capped tubes containing sterilized water was grown and incubated at room temperature for 14 days on potato dextrose agar (PDA) in $9 \mathrm{~cm}$ plastic Petri dishes.

A conidial suspension of $F$. sporotrichioides spores were prepared and harvested by rinsing the cultures with sterilized distilled water.

The suspension was filtered through three layers of cheesecloth to remove most of the mycelia. Spore concentration was adjusted to $1 \times 10^{6}$ spores $/ \mathrm{ml}$ by counting spores with Bürker hemocytometer. The spore suspension was used for foliar spray.

\section{Field experiment}

Field trial was conducted on a sandy loam soil at a non-cultivated land of Hajdúhadház (East Hungary) (GPS coordinates: 47.70989621 .580633 ) during the summer of 2017.

The plots were $6 \mathrm{~m}$ long and $3 \mathrm{~m}$ apart. The field was naturally infested with $A$. syriaca plants. Within each plot 10 test plants were randomly selected and marked by using a piece of blue string.

Treatment consisted of $F$. sporotrichioides conidia $1.0 \times 10^{6}$ conidia/ml suspended in sterile distilled water with one drop of Trend $\AA$ (nonionic surfactant, DuPont). In the first plot common milkweed plants were approximately $50 \mathrm{~cm}$ high and in the second plot the plants were at early flowering stage.

For the experiment environmental conditions at the time of the inoculation and for the $24 \mathrm{~h}$ period following the treatment were: temperature at the inoculation $22^{\circ} \mathrm{C}$ with a RH of $69 \%$. The highest temperature for the $24 \mathrm{~h}$ period was $27{ }^{\circ} \mathrm{C}$ and the lowest temperature was $12{ }^{\circ} \mathrm{C}$. The selected plants were monitored for disease development at 7-day intervals for 42 days.

The artificial inoculation method was foliar spray of an aqueous spore suspension $\left(1 \times 10^{6}\right.$ spores $\left./ \mathrm{ml}\right)$ using a standard $100 \mathrm{ml}$ sprayer.

Untreated plots depended on natural inoculum.

On the $28^{\text {th }}$ day followed by the inoculation tissues were dissected from the leaves of artificially infested plants, disinfected (3 $\mathrm{min}$ in $0.5 \% \mathrm{v} / \mathrm{v} \mathrm{NaOCl}$ ) and plated on antibiotic Sabouraud dextrose agar (SDA) for recovery of the applied fungus.

\section{RESULTS AND DISCUSSION}

The fungus was identified as Fusarium sporotrichioides Sherb. based on microscopic examination of diseased tissue and morphological characteristics of the colony. The morphology of the isolate is identical to that reported previously for this species (Tóth 2017).

\section{Fungal isolate and inoculum}

The fungus was readily isolated from diseased tissue and it sporulated abundantly on PDA. After reinoculated onto healthy leaves, the fungus was highly virulent and necrotized the leaf tissues after three weeks, while the controls remain healthy.

The morphological characters of the colonies on potato dextrose agar (PDA) and the macro-, meso- and microconidia on sporodichia on synthetic low-nutrient agar (SNA) were analogous of those specifications which were described for Fusarium sporotrichioides Sherb. by Leslie and Summerell (2006).

$F$. sporotrichioides is a rapidly growing fungus (fill the plate less than 7 days) and produces abundant sporodichia.

The colony white first but with age the pigment darkens (Figure 1).

\section{Figure 1: Fusarium sporotrichioides -} colony morphology on PDA

(A-B: 1 week after the transfer A - front, B - reverse)
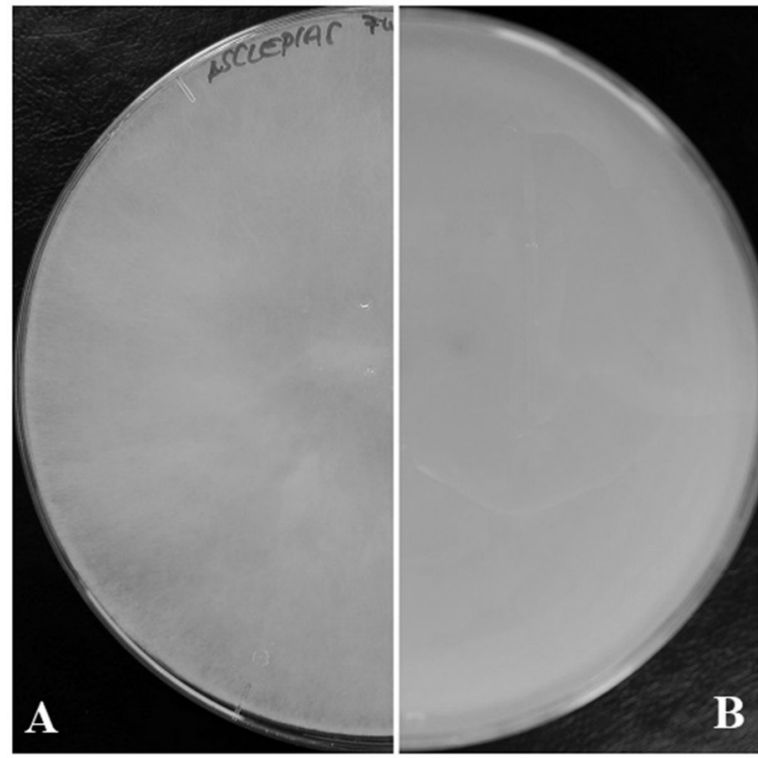

Source: Tóth (2017)

The examined strains formed red pigment after 3 weeks in the agar and abundant, white aerial mycelia. The macroconidia were mostly falcate and relatively abundant. The apical cells of the spores were curved and tapering. The basal cells of the spores were variable, neither foot-shaped, nor notched. The number of septa were 3,4 or 5 . The mesoconidia were fusoid with may be up to 5 septate, while microconidia were aseptate with pyriform and 1 septate with fusoid shape (Figure 2).

\section{Field experiment}

Application were made at midday with a hand-held sprayer. 
No visual infectivity or injury was observed on nearby plants (Erigeron canadensis, Calamagrostis epigeios) using this inoculum formulation under field conditions.

Figure 2: Macro-, meso- and microconidia of Fusarium sporotrichioides - characteristics to the species

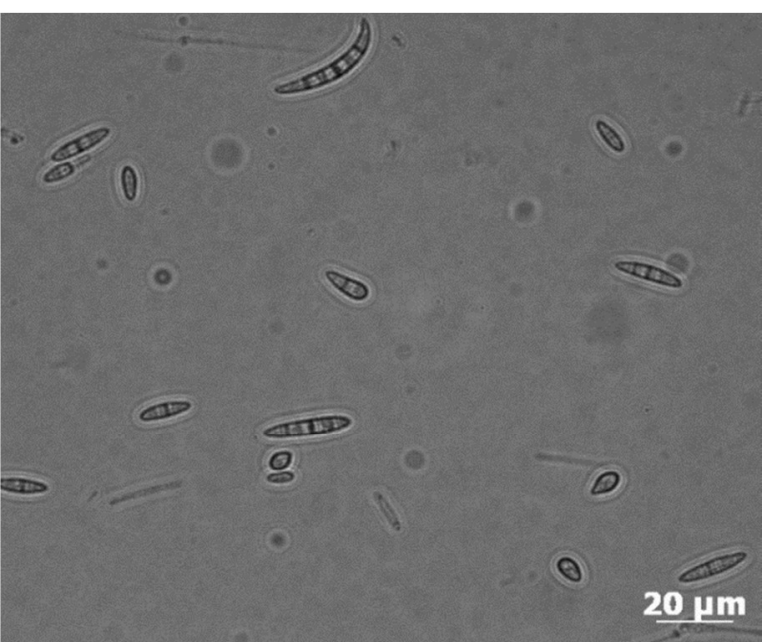

Source: Tóth (2017)

The efficacy of Fusarium sporotrichioides against A. syriaca plants at $\sim 50 \mathrm{~cm}$ height

7 days after treatment common milkweed plants showed only slight leaf discoloration, the main symptom was the curled shape of the leaves. At the third week the lower leaves died and fallen rapidly. After six weeks the apical leaves showed severe tissue degradation (Figure 3).

Figure 3: $\mathbf{5 0} \mathrm{cm}$ high plants of common milkweed (Asclepias syriaca $\mathrm{L}$.) treated with $1.0 \times 10^{6}$ inoculum concentration of Fusarium sporotrichioides

(A - spoon-shaped leaves after one week, B - leaf fall after three weeks, $\mathrm{C}$ - severe leaf fall and stem wilt after six weeks of treatment)
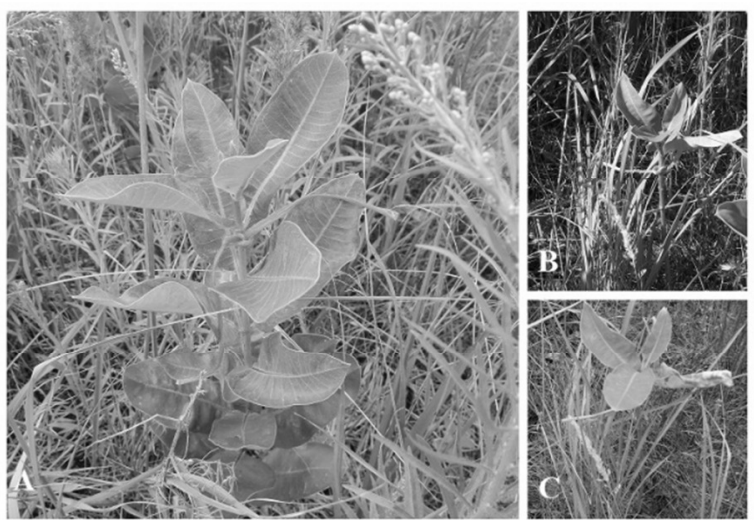

Source: Tóth (2017)

It is important that the height of the plants did not changed in this six-week period and these plants never reached the flowering stage, thus no seed production was observed.
The efficacy of Fusarium sporotrichioides against A. syriaca plants at the early flowering stage

One week after the inoculation small chlorotic spots appeared on the leaves of $A$. syriaca plants. In the third week at the middle of the plants some leaves became chlorotic and later necrotic, few of them had fallen onto the ground. The next step happened after six weeks when the leaves have already been exhibited discoloration rapidly curled and died. Other primary symptom (stem dieback from the apical part) was severe (Figure 4).

Figure 4: Common milkweed (Asclepias syriaca L.) plants at early flowering stage treated with $1 \times 10^{6}$ inoculum concentration of Fusarium sporotrichioides

(A - plant after foliar spray, B - chlorosis on middle leaves after three weeks, $\mathrm{C}$ - severe drying of leaves and stem after six weeks of treatment)

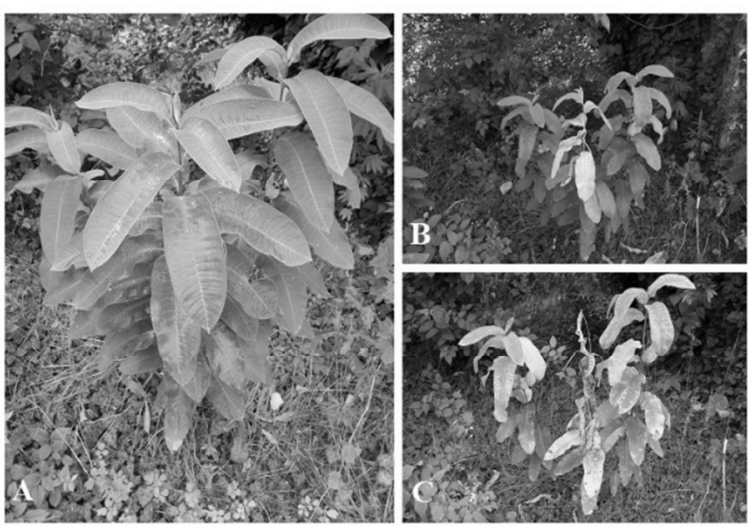

Source: Tóth (2017)

It is important to note that none of the artificially inoculated plants produced viable seeds after the treatment.

\section{CONCLUSION}

The $F$. sporotrichioides isolates from common milkweed (A. syriaca) plants were identified on the base of the morphology. The reproducible method for production of conidia was on several solid substrates was elaborated.

According to results of field evaluation we can highlight the fact that our FS04 isolate was highly virulent against common milkweed. In field tests, almost all plants treated with $1.0 \times 10^{6}$ inoculum concentration were controlled at 42 days after treatment. The fungus sporulated profusely on infected tissue and devastate common milkweed leaves when reinoculated onto them, thus fulfilling Koch's postulates.

It is important to find the proper timing of applications in the most susceptible growth stages to optimize the chances for successful control. In our experiment, the highest weed control occurred on common milkweed plants at early flowering stage.

These experiments demonstrated that isolate FS04 of $F$. sporotrichioides may be an effective bioherbicide for controlling $A$. syriaca a problematic, invasive weed species. 
Further research is a needed to define the host range of the fungus testing various cultivated plants and cultivars. Special consideration will be given to the effects of this pathogen on non-cultivated areas (like National Parks, State Forests), where it cannot infect cultivated plant species like cucurbits, sunflower, barley, wheat, and corn.

\section{ACKNOWLEDGEMENT}

The publication is supported by the EFOP 3.6.116-2016-00022 project. The project is co-financed by the European Union and the European Social Fund.

\section{REFERENCES}

Almási, A.-Ekés, M.-Hunyadi, K. (1999): Natural occurence of tobacco mosaic tobamovirus (TMV) on common milkweed (Asclepias syriaca L.) in Hungary. Acta Phytopathologica et Entomologica Hungarica. 34. 3: 169-176.

Altomare, C.-Petrini, O.-Logrieco, A.-Bottalico, A. (1997): Taxonomic relationships among the toxigenic species Fusarium acuminatum, Fusarium sporotrichioides and Fusarium tricinctum by isozyme analysis and RAPD assay. Canad. J. Bot. 75: 1674-1684.

Anderson, W. P. (1999): Perennial weeds. Characteristics and identification of selected herbaceous species. Iowa State University Press. Iowa. USA. 228.

Bagi I. (1999): A selyemkóró (Asclepias syriaca L.) - Egy invazív faj biológiája, a védekezés lehetőségei. Kitaibelia. 4. 2: 289295.

Bhowmik, P. C.-Bandeen, J. D. (1976): The biology of Canadian weeds. 19. Asclepias syriaca L. Can. J. Plant Sci. 56: 579-589.

Cramer, G. L.-Burnside, O. C. (1981): Control of common milkweed (Asclepias syriaca). Weed Science. 29. 6: 636-640.

Cramer, G. L.-Burnside, O. C. (1982): Distribution and interference of common milkweed (Asclepias syriaca) in Nebraska. Weed Science. 30. 385-388.

Evetts, L. L. (1970): Ecological studies with common milkweed M.Sc. Thesis, University of Nebraska. Lincoln. Neb. USA. 70.
Horváth J.-Mamula D.-Salamon P. (1983): Az Asclepias syriaca L. (Asclepiadaceae) uborka mozaik vírus fogékonysága és szerepe a vírus ökológiájában. Növényvédelem. 19. 8: 352-353.

Horváth Z. (1984): Adatok az Asclepias syriaca L. (Asclepiadaceae) magprodukciójának és csírázásbiológiájának komplex ismeretéhez. Növényvédelem. 20. 4: 158-166.

Horváth Z.-Szalay-Marzsó L. (1984): Aphis nerii B.D.F. az oleánder levéltetű megjelenése Magyarországon. Növényvédelem. 20. 4: 189-190.

Leslie, J. F.-Summerell, B. A. (2006): The Fusarium Laboratory Manual. Blackwell Professional. Ames. Iowa. USA. 338.

Mathew, F. M.-Kirkeide, B.-Gulya, T.-Markell, S. (2010): First report of pathogenicity of Fusarium sporotrichioides and Fusarium acuminatum on sunflowers in the United States. Pl. Health Progr. Online: 1-3.

Mulenko, W.-Majewski, T.-Ruszkiewicz-Michalska, M. (2008): A Preliminary Checklist of Micromycetes in Poland. W. Szafer Institute of Botany. Polish Academy of Sciences. 9: 752.

Tóth T. (2017): Két mikroszkopikus gombafaj együttes károsítása szíriai selyemkórón (Asclepias syriaca L.) a Hajdúsági kistérségben. Agrártudományi Közlemények. 72: 189-195.

Ulmann, M. (1951): Wertvolle Kautschukpflanzen des gemassingten Klimas. Akademie-Varlag. Berlin. 562. 